\title{
ETOS KERJA WANITA PEKERJA ROTAN DI DESA BARU DUSUN SELATAN KABUPATEN BARITO SELATAN KALIMANTAN TENGAH
}

\author{
Rahmaniar \\ Intitut Agama Islam Negeri (IAIN) Palangkaraya \\ e-mail:rabmanian@gmail.com \\ Hamdanah, Jirhanuddin, Zainal Arifin, Enriko Tedja S. Kusuma \\ Intitut Agama Islam Negeri (IAIN) Palangkaraya \\ e-mail: bamdanah@gmail.com,jirban1959@gmail.com, \\ mzainalarifin.iain@yahoo.com enriko.iain@yahoo.com \\ DOI: http:/ / dx.doi.org/10.30983/islam_realitas.v3i2.407
}

\begin{abstract}
Some scholars argue that a farmer's mental attitude, including the main worker or laborer, is a subsintence attitude. The above opinion, it seems not entirely acceptable, especially if faced with the reality of the lives of working women or rattan workers in Dusun Baru, South Barito Regency, Central Kalimantan Province. The research of qualitative research with phenomenological study is aimed to find out work ethic of working woman labor in Dusun Baru Central Kalimantan. The result of the research shows that there are two categories of their work etbic level, namely work ethic, first, "Uluwat bawi ji rubber bagawi" (Dayak Bakumpai Language) means woman having high work ethic, with the following characteristics: have high working hours (ranged between 38 to 45 hours per week), clever with respect to time, work quality oriented, able to see and take advantage of existing opportunities, have today's principles must be better than yesterday and tomorrow should be better than today, view that education for children is very important and life must be frugal. Both "Bawi jijida hawas ban bagawi" (Dayak Bakumpai Language), meaning low woman work ethos, with characteristics as follows: The number of working hours is low (ranging between 18 to 28 hours per week), not able to take advantage of time, less creative viewing and taking advantage of opportunities that do not have a better foresight
\end{abstract}

Keywords: Work Ethic, Women, Rattan Workers.

\section{Abstrak}

Sebagian ahli berpendapat bahwa sikap mental petani, termasuk pekerja atau buruh yang utama, adalah sikap subsintens. Pendapat di atas, tampaknya tidak seluruhya dapat diterima, terutama jika dihadapkan dengan realitas kehidupan wanita pekerja atau buruh rotan di Desa Baru Kecamatan Dusun Selatan, Kabupaten Barito Selatan, Provinsi Kalimantan Tengah. Penelitian penelitian kualitatif dengan kajian fenomenologis ini bertujuan untuk mengetahui etos kerja wanita pekerja/buruh rotan di Desa Baru Kalimantan Tengah. Hasil penelitian menunjukkan ada dua kategori tingkatan etos kerja mereka, yakni etos kerja, pertama, ulub bawi ji karetap bagawi (Bahasa Dayak Bakumpai) artinya wanita yang memiliki etos kerja tinggi, dengan ciri-ciri sebagai berikut: memiliki jam kerja yang tinggi ( berkisar antara 38 sampai 45 jam per minggu), pandai menghargai waktu, berorientasi pada kualitas kerja, mampu melihat dan memanfaatkan peluang yang ada, memiliki prinsip hari ini harus lebih baik dari kemaren dan besok harus lebih baik dari hari ini, berpandangan bahwa pendidikan bagi anak sangat penting dan hidup harus hemat. Kedua Bawi jijida hawas cangkal bagawi (Bahasa Dayak Bakumpai), artinya wanita yang rendah etos kerjanya, dengan ciri-ciri sebagai berikut: Jumlah jam kerja rendah (berkisar antara 18 sampai dengan 28 jam perminggu), tidak mampu memanfaatkan waktu, kurang kreatif melihat dan memanfaatkan peluang yang ada tidak memiliki pandangan ke depan yang lebih baik

Kata Kunci: Etos Kerja, Wanita, Pekerja Rotan 


\section{Latar Belakang}

Allah membebani hamba-Nya kewajiban untuk berusaha atau bekerja. ${ }^{1}$ Manusia adalah homo faber, dengan bekerja manusia menyatakan eksistensinya dalam kehidupan masyarakat. ${ }^{2}$ Hamzah Ya'qub dalam bukunya menegaskan bahwa bekerja menurut Islam adalah sesuatu yang digariskan bagi umat manusia. Bekerja adalah sesuai dengan kodratnya sekaligus menjadi cara untuk memperoleh kebahagiaan dunia dan akhirat. Ajaran Islam mendorong supaya berusaha sungguh-sungguh untuk menguasai pekerjaannya. Dengan demikian, setiap Muslim tidak dapat dipisahkan dengan kerja, dengan kerja berarti ia menjunjung martabat kemanusiaannya. ${ }^{3}$

Bekerja saja tidaklah cukup, akan tetapi juga etos kerja yang baik pula. Namun, tidak semua orang yang menekuni bidang pekerjaan memiliki semangat kerja yang baik, sebagaimana hasil penelitian sebagian para ahli ada yang memandang sinis terhadap etos kerja petani dan buruh tani ${ }^{4}$.

Baxter, penulis Christian Directory edisi kedua tahun 1678, menyatakan bahwa petani hanya memiliki sedikit persesuaian dalam pola hidup asketisme rasional. ${ }^{5}$ Koentjaraningrat menegaskan, sikap mental petani yang utama adalah sikap subsistens. Artinya petani bekerja adalah untuk sekedar memenuhi kebutuhan

${ }^{1}$ Nurcholish Madjid, Cendekiawan dan Religiusitas Masyarakat (Jakarta: Paramadina, 1999), h. 77.

${ }^{2}$ Musa Asy'arie, Islam Etos dan Pemberdayaan Ekonomi Umat (Yogyakarta: LESFI, 1997), h. 40.

${ }^{3}$ Hamzah Ya'qub, Etos Kerja Islami, Cet. III (Jakarta: CV Pedoman Ilmu Jaya, 2001), h. 6-7.

4 Alfisyah, Alfisyah, "Dinamika Ekonomi dan

Perkembang Perdagangan Urang Banjar", Jurnal Kebudayaan Kandil-Melintas Tradisi, 6.16, 2008, h. 56-68.

5 Weber, The Protestant, Ethic and the Spirit of Capitalism, Translated by Talcott Parsons (London and New York: Routledge, 1996), h. 232. hidup. Jika kebutuhan hidup sudah terpenuhi maka orang tidak perlu bekerja keras lagi. ${ }^{6}$

Hal ini didukung oleh beberapa pendapat yang mengatakan bahwa petani termasuk buruh tani memiliki sikap mental pemalas tidak mau bekerja keras, sikap mental yang tidak mendorong pembangunan, serta tidak memiliki semangat kapitalis. Akan tetapi tampaknya tidak semua pendapat tersebut dapat diterima, terutama jika dihadapkan dengan buruh pekerja rotan, di Desa Baru.

Observasi selintas menggambarkan bahwa wanita pekerja rotan di desa tersebut masih banyak yang memiliki sikap mental sebagai pekerja keras (uluh ji kabariat bagawi (Bahasa Dayak Bakumpai) Hal ini terlihat dari kualitas kerja, kuantitas jam kerja dan kemampuan mengelola dan menghargai waktu serta memililiki visi ke depan yang baik. Realitas demikian termasuk salah satu bagian yang membuat peneliti termotivasi untuk melakukan penelitian terhadap etos kerja wanita pekerja rotan di Desa Baru. Berdasarkan latar belakang di atas, penelitian ini bermaksud untuk mengetahui etos kerja wanita pekerja rotan di Desa Baru.

\section{Etos Kerja dalam Perspektif Teori}

Dalam Websters World University Dictionary disebutkan etos ialah sifat dasar atau karakter yang merupakan kebiasaan dan watak bangsa atau ras. ${ }^{7}$ Menurut Geertz, seperti yang dikutip Taufik Abdullah, etos adalah sikap hidup yang mendasar terhadap diri dan dunia yang

${ }^{6}$ Amri Marzali, Antropologi dan Pembangunan Indonesia (Jakarta: Prenada Media, 2005), h. 143.

${ }^{7}$ Lewis Mulford Adam, et.al, Websters World University Dictionary (Washington DC: Publishers Company Inc., 1965), h. 331. 
terpancar dalam kehidupan. Etos adalah aspek evaluatif yang bersifat menilai. ${ }^{8}$

Beranjak dari pengertian di atas dapat dipahami bahwa etos bisa bermakna karakter, cara hidup, kebiasaan seseorang, motivasi atau tujuan moral seseorang serta pandangan hidup mereka, yakni gambaran, cara bertindak ataupun gagasan yang paling komprehensif mengenai tatanan. Dengan kata lain, etos adalah aspek evaluatif sebagai sikap mendasar terhadap diri dan dunia mereka yang direfleksikan dalam kehidupannya.

Kerja merupakan penggunaan kekuatan fisik atau daya mental untuk melakukan sesuatu. 9 Sementara itu, barthos menyampaikan bahwa bekerja adalah melakukan kegiatan dengan maksud memperoleh atau membantu memperoleh penghasilan atau keuntungan selama paling sedikit satu jam dalam satu minggu yang lalu. Bekerja selama satu jam tersebut harus dilakukan berturut-turut dan tidak terputus. ${ }^{10}$

Berdasarkan pendapat para ahli di atas tentang pengertian kerja, dapat ditarik kesimpulan pokok antara lain: 1). Kerja itu merupakan aktivitas bertujuan dan dilakukan secara sengaja. 2). Kerja dalam konteks ekonomi merupakan usaha menyelenggarakan proses untuk menghasilkan sesuatu (upaya memperoleh hasil). 3). Kerja dapat bersifat lahir (fisik) dan batin (non fisik).

\section{Etos Kerja dalam Islam}

Nilai akidah dalam etos kerja Islam adalah nilai-nilai ketuhanan yang mendasari etos kerja seorang Muslim dalam bekerja. Nilai-nilai ketuhanan yang berpusat pada

${ }^{8}$ Taufik Abdullah, (ed), Agama, Etos Kerja dan Perkembangan Ekonomi, cet. Kedua Jakarta: LP3S, 1982), h. 3.

9 Hornby, A.S., Oxford Advanced Learner's Dictionary of Current English (Oxford: Oxford University Press, 1955), h. 1375.

${ }^{10}$ Basir Barthos, Manajemen Sumber Daya Manusia Suatu Pendekatan Makro, Cet. Kelima (Jakarta: PT Bumi Aksara, 1999), h.17. akidah tauhid yang mempunyai prinsip hanya ada satu Tuhan saja, yang dalam etos kerja akan membentuk suatu sikap yang tidak hanya mementingkan diri sendiri, tetapi juga tanggung jawab sosial. Suatu sikap yang meletakkan bekerja tidak hanya untuk mencari sesuap nasi, tetapi juga melaksanakan kewajiban agama. Suatu sikap yang memandang sesuatu tidak hanya pada dimensi yang material saja, tetapi juga yang spiritual. Suatu sikap yang memandang bahwa semua yang ada ini bersumber dari Realitas Tunggal ${ }^{11}$.

Musa Asy'ari menambahkan, suatu hal yang tidak kalah pentingnya bahwa konsep etos kerja pada hakikatnya dapat dilihat dan dilacak sebagai bagian dari filsafat manusia. Manusia menurut Islam adalah kesatuan 'abd dan khalifah, sebagai ' $a b d$, maka manusia harus taat dan patuh pada Tuhan, pada ajaran dan perintah-Nya yang universal. Sedangkan sebagai khalifah, manusia dengan kemampuan konseptualnya, meneruskan tugas penciptaan di muka bumi, untuk menciptakan kemakmuran dan kesejahteraan bersama. ${ }^{12}$ Untuk dapat hidup sejahtera dan menjadi pemakmur bumi harus diiringi dengan bekerja yang rajin.

Etos kerja dalam Islam pada hakekatnya tidak lepas dari tujuan diciptakannya manusia itu sendiri, yakni ibadah, sebagaimana firman Allah dalam surah $A \dot{z}$ Żäriyàt [51]: 56.

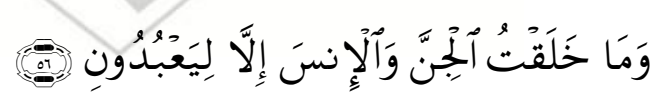

Artinya: Dan Aku tidak menciptakan jin dan manusia melainkan supaya mereka mengabdi atau beribadah kepada-Ku.

Ibadah oleh para ulama diklasifikasikan menjadi dua bagian: pertama, ibadah mahdah, yakni ritus-ritus keagamaan, seperti salat,

${ }^{11}$ Musa Asy'arie, Islam Etos Kerja dan Pemberdayaan Ekonomi Umat (Yogyakarta: LESFI, 1997), h. 68-69.

${ }^{12}$ Musa Asy'arie, Islam Etos Kerja dan Pemberdayaan Ekonomi....., h. 70 . 
zakat, puasa, haji, zikir, membaca al-Quran dan sebagainya. Kedua, ibadah ghayr mahdah, yakni aktivitas-aktivitas ibadah selain ibadah mahdah, yang biasa disebut dengan ibadah sosial, seperti : membangun jembatan, jalan, madrasah, bekerja, memikirkan kepentingan umat dan sebagainya. ${ }^{13}$

Upaya mewujudkan ibadah mạ̣dah, seperti: salat, membayar zakat dan naik haji. Begitu pula dengan ibadah ghayr mahdah, seperti: menggiatkan kegiatan pendidikan dengan membantu melengkapi sarana prasana, kegiatan pertanian dengan membantu petani membuat irigasi dan pengadaan bibit dan sebagainya sehingga kesejahteraan meningkat. Semua itu bisa terlaksana jika memiliki kelebihan. Kelebihan tidak mungkin datang dengan sendirinya, tanpa ikhtiar dan kerja keras. ${ }^{14}$ Menghayati bahwa tujuan hidup manusia pada hakekatnya adalah ibadah dapat mendorong etos kerja.

\section{Teori Etos Kerja}

Max Weber dalam karyanya The Protestant Ethic and the Spirit of Capitalism menjelaskan hasil penelitiannya mengenai pengaruh reformasi (yang dimaksud Agama Protestan Sekte Calvinisme) terhadap semangat kapitalisme. Meskipun ia tidak membuat klaim bahwa semangat kapitalisme timbul hanya akibat reformasi tetapi Weber menekankan bahwa kekuatan atau nilai agama itu ternyata ikut ambil bagian secara kualitatif terhadap semangat pembentukan kapitalisme, dan secara kuantitatif telah menyebarluaskan semangat itu sampai ke negeri seberang. Berikut ini pemikiran Weber yang berkaitan dengan hal tersebut.

Taufik Abdullah juga mengatakan jika membicarakan tentang etos kerja dan

${ }^{13}$ Lebih rinci lihat M. Abdul Kodir, Islam Konseptual dan Kontekstual (Bandung: Itqan, 1993), h. 72.

${ }^{14}$ Lihat Hamzah Ya'qub, Etos Kerja Islami, Cet III (Jakarta: Pedoman Ilmu Jaya, 2001), h. 22-24. kaitannya dengan agama, maka Weber dikenal sebagai pencetus teori tersebut. Namun teori yang dikemukakan Max Weber juga ada yang mempertentangkannya dengan teori Karl Marx tentang kapitalisme. Samuelson, ahli sejarah ekonomi Swedia, tanpa segan-segan menolak dengan keras keseluruhan tesis Weber. ${ }^{15}$

Meskipun teori etos kerja pertama kali diperbincangkan di belahan dunia barat dan tidak ada pendapat yang tunggal terhadapnya, yakni ada yang membantahnya. Namun apa yang diungkapkan Weber dalam tesisnya tampak menarik perhatian para peneliti sosial keagamaan untuk melihat kemungkinan adanya keterkaitan ajaran agama dengan etos kerja atau semangat pembangunan pada bangsa dan negara lain, tidak terkecuali di Indonesia.

Uswatun Hasanah dalam bukunya Etos Kerja Sarana Menuju Puncak Prestasi menyebutkan, bahwa ada dua paham, yakni mentalisme dan strukturalisme ketika membicarakan masalah etos kerja. ${ }^{16}$ Arief Budiman juga mengungkapkan hal yang senada, di mana ia menjelaskan bahwa di Indonesia saat ini terlihat ada dua aliran besar yang membahas teori tentang etos kerja, pertama adalah penganut paham mentalisme dan kedua penganut paham historis struktural. ${ }^{17}$

Paham mentalisme secara garis besar menganggap bahwa struktur alam atas atau alam pemikiran manusia, merupakan bagian dari kesadaran manusia di dalam upaya untuk dapat mengubah atau menentukan sejarah dalam memaknai dunia. Struktur alam pemikiran manusia menjadi alat yang sangat penting dalam upaya menafsirkan lebih lanjut terhadap dunia yang akan punya pengaruh

\footnotetext{
${ }^{15}$ Taufik Abdullah (Ed), Agama, Etos..., h. 4-5.

${ }^{16}$ Uswatun Hasanah, Etos Kerja ..., h. 10.

${ }^{17}$ M. Dawam Rahardjo, Islam dan ..., h. 248.
} 
terhadap sikap dan tingkah laku seseorang dalam gerak hidup di dunia ini. ${ }^{18}$

Apabila berbicara masalah etos kerja, maka tidak bisa dilepaskan dari asumsi dasar bahwa peran manusia sebagai pelaku dari kerja itu sendiri sangat penting. Manusia sebagai pelaku utama punya peran penting yang sangat menentukan. Artinya, kesadaran manusia atau nilai-nilai yang berada dalam diri manusia menjadi faktor yang sangat menentukan sikap manusia dalam memaknai dunia ini ${ }^{19}$.

Menurut Wahyuni, pembahasan mengenai etos kerja berarti mempersoalkan sumber motivasi yang mendasari seseorang bertindak. Dari sudut teoritis membawa pada persoalan kemungkinan adanya hubungan yang saling mendukung antara keadaan rohaniah seseorang dengan sistem perilaku. Bagaimana sumber motivasi yang berasal dari keadaan batin seseorang mampu mewarnai sikap kerja, sehingga dengan demikian kerja merupakan sebuah bentuk pencerminan dari keadaan batin seseorang ${ }^{20}$.

Paham mentalisme dianut oleh beberapa pemikir besar dunia seperti Max Weber. Ia melihat sikap mental seseorang sangatlah penting dalam memaknai dunia ini. ${ }^{21}$

Tesis yang dihasilkan oleh Max Weber tersebut tetap memunculkan berbagai tanggapan dari berbagai pihak yang bernada menentang sehingga ada semacam paradigma tandingan yang mengatakan bahwa bukan kesadaran yang menentukan keadaan dan

${ }^{18}$ Uswatun Hasanah, Etos Kerja ..., h. 11.

19 Alfisyah, Alfisyah, "Dinamika Ekonomi dan Perkembang Perdagangan Urang Banjar", Jurnal Kebudayaan Kandil-Melintas Tradisi, 6.16, 2008, h. 56-68.

20 Wahyuni, Devi, "Kebijakan Kepemimpinan Perempuan dalam Pendidikan Islam: Refleksi Atas Kepemimpinan Rky Rahmah El Yunisiyah." Islam Realitas: Journal of Islamic \& Social Studies, 3.1, 2017, h 38-47.

${ }^{21}$ Uswatun Hasanah, Etos Kerja ..., h. 11-12. waktu, melainkan kondisilah yang menentukan kesadaran. $^{22}$

Munculnya paradigma tandingan tidak harus dipahami sebagai bentuk saling mengancam dan melemahkan antara satu dengan yang lainnya, namun sebenarnya lebih bisa dimaknai sebagai alternatif kemungkinan lain yang perlu juga diperhitungkan dalam mengkaji masalah yang berhubungan dengan etos kerja ${ }^{23}$.

Adanya dua aliran atau paham tentang etos kerja seperti disinggung di atas, menyebabkan pemahaman akan etos kerja tidak hanya dapat ditelusuri melalui nilai-nilai yang bersumber dari kepercayaan seseorang atau kelompok, tetapi lebih dari itu etos kerja juga dapat dilacak melalui kondisi struktur lingkungan, baik sosial, budaya, maupun geografinya.

\section{Kedudukan Kerja dalam Islam}

Manusia adalah bomo faber, dengan bekerja manusia menyatakan eksistensinya dalam kehidupan masyarakat. ${ }^{24}$ Jika ditinjau dari sisi keIslaman, kerja merupakan sesuatu yang digariskan bagi umat manusia. Bekerja adalah sesuai dengan kodratnya sekaligus menjadi cara untuk memperoleh kebahagiaan dunia dan akhirat. Ajaran Islam mendorong semua orang supaya berusaha sungguhsungguh untuk menguasai pekerjaannya... ${ }^{25}$

Bekerja bagi seorang Muslim merupakan suatu kewajiban, karenanya pengerahan semua aset, pikir dan zikir mesti dikerahkan. Secara hakiki, bekerja bagi seorang Muslim memiliki nilai ibadah. ${ }^{26}$ Yusuf al-Qardhawi mengungkapkan bahwa bekerja adalah bagian

${ }^{22}$ M. Dawam Rahardjo, Islam dan..., h. 248.

23 Prasetyo, P. E., "Etos Kerja Wanita dalam Meningkatkan Kesejahteraan Keluarga", Jurnal Forum Ilmu Sosial, Vol. 32, 2005, h. 32.

${ }^{24}$ Musa Asy'arie, Islam Etos ..., h. 40.

${ }^{25}$ Hamzah Ya'qub, Etos Kerja..., h. 6-7.

${ }^{26}$ Toto Tasmara, Membudayakan Etos Kerja Islami (Jakarta: Gema Insani Press, 2002), h. 25. 
dari ibadah. ${ }^{27}$ M. Quraish Shihab menambahkan supaya kerja yang dilakukan seseorang memiliki nilai ibadah maka harus disertai dengan keikhlasan. ${ }^{28}$

\section{Ciri-ciri Etos Kerja Tinggi}

Dumairy menyebutkan; seseorang dikatakan bekerja penuh (tinggi) apabila jam kerjanya telah mencapai setidak-tidaknya 35 jam kerja dalam seminggu. Di daerah pedesaan jumlah jam kerja yang paling banyak dijalani para pekerja adalah antara 35 hingga 44 jam dalam seminggu. ${ }^{29}$ Tinggi rendahnya etos kerja selain bisa diukur melalui jumlah jam kerja, juga dapat dilihat dari sisi kualitas kerja, kesungguhan dan idealisme pekerja. Djamaluddin Ancok menyebutkan bahwa orang yang etos kerjanya baik atau tinggi, memiliki ciri-ciri sebagai berikut : 1. Selalu ingin bekerja keras untuk mencapai kualitas kerja yang sebaik-baiknya 2. Selalu ingin meningkatkan prestasi kerjanya dari hari ke hari. Mereka tergolong orang yang menerapkan prinsip hidup bahwa apa yang diperbuat hari ini harus lebih baik dari apa yang telah diperbuat kemaren; dan 3. Selalu merasa tidak puas dengan hasil pekerjaan yang asal jadi. Mereka akan puas dengan pekerjaan yang bermutu tinggi. ${ }^{30}$

Ahmad Janan Asifudin, mengutip pendapat Gunnar Myrdal, menyebutkan ada tiga belas sikap yang menandai etos kerja tinggi pada seseorang : 1. efisien; 2. rajin; 3. teratur; 4. disiplin/tepat waktu; 5. hemat; 6. jujur dan teliti; 7. rasional dalam mengambil keputusan

${ }^{27}$ Yusuf al-Qardhawi, Norma dan Nilai Ekonomi Islam,Terj. Zainal Arifin dan Dahlia Husin Jakarta: Gema Insani Press, 1997), h. 107.

${ }^{28}$ M.Quraish Shihab, Secercab Cabaya Ilabi Hidup Bersama Al- Quran (Bandung: Mizan, 2007), h. 306.

${ }^{29}$ Dumairy, Perekonomian Indonesia,Cet. II (Jakarta: PT. Gelora Aksara Pratama, 1997), h. 83-84.

30 Djamaluddin Ancok, Nuansa Psikologi Pembangunan (Yogyakarta: Pustaka Pelajar,1995), h. 165. Lihat Psikologi Terapan, oleh Djamaluddin Ancok, h. 175. dan tindakan; 8. bersedia menerima perubahan; 9. gesit dalam memanfaatkan kesempatan; 10. energik; 11. ketulusan dan percaya diri; 12. mampu bekerjasama; dan 13 mempunyai visi yang jauh ke depan. ${ }^{31}$ Disamping ciri-ciri yang telah diungkapkan di atas, maka ada satu hal yang sangat penting diperhatikan untuk meningkatkan etos kerja yang baik/tinggi, yakni sehatnya jasmani dan rohani. Kesehatan fisik dan mental tentunya menjadi pra kondisi dan sekaligus sebagai modal utama bagi orang yang bersangkutan untuk mendukung etos kerja yang tinggí.

\section{Penelitian yang Relevan}

Ada beberapa hasil penelitian yang dianggap ada hubungannya dengan penelitian yang dilakukan di antaranya yang dilakukan Mubyarto dkk di Provinsi Nusa Tenggara Timur (NTT) yang meliputi beberapa desa, (Desa Sumba, Rote, Sabu, dan Timor). menjelaskan bahwa sebab ketertinggalan/lambannya pembangunan di NTT dibandingkan dengan provinsi lain ternyata ada kaitannya dengan etos kerja yang rendah dan kohesi sosial masyarakat yang lemah. Disarankan pemerintah perlu untuk meningkatkan etos kerja masyarakat Sumba, Rote, dan Timor Nusa Tenggara Timur (NTT) sekaligus mempererat kohesi sosial, agar provinsi itu dapat setara dengan provinsi lainnya. ${ }^{32}$

${ }^{31}$ Ahmad JananAsifudin 'Etos Kerja Islami (Tela'ah Psikologi)", Disertasi Program Pascasarjana IAIN Sunan Kalijaga Yogyakarta, 2003, h. 47. Salaa, Jeiske, "Peran Ganda Ibu Rumah Tangga dalam Meningkatkan Ekonomi Keluarga di Desa Tarohan Kecamatan Beo Kabupaten Kepulauan Talaud", Jurnal Holistik, 3.2, 2015, h. 43.

${ }^{32}$ Mubyarto dkk, Etos Kerja dan Kohesi Sosial Masyarakat Sumba, Rute, Sabu dan Timor Nusa Tenggara Timur (NTT) (Yogyakarta: Aditya Media, 1991), h. 171. Desky, Harjoni, "Pengaruh Etos Kerja Islami dan Gaya Kepemimpinan terhadap Kinerja Karyawan Rumah Makan Ayam Lepaas Lhokseumawe", Inferensi Jurnal Penelitian Sosial Keagamaan, 8.2, 2014, h. 459-478. Gorontalo, Rifani, "Modernisasi dan Perubahan Sosial 
Buku tersebut merupakan metamorfosis dari disertasi Ahmad Janan Asifudin. Permasalahan yang diangkat dalam disertasi tersebut mengenai apa dan bagaimana etos kerja islami, dan bagaimana telaah psikologi terhadapnya. ${ }^{33}$ Hasil penelitian itu menjelaskan bahwa karakteristik etos kerja yang islami harus digali dan dirumuskan berdasarkan konsep iman sebagai fondasi dan amal saleh sebagai bentuk yang terbangun di atasnya. Etos kerja islami yang tinggi hendaknya dilandasi dengan moralitas seperti sifat amanah, tanggung jawab, menepati janji, hidup hemat, penuh kesabaran, memperhatikan dimensi waktu (masa lalu dan masa yang akan datang) dan tawakkal kepada Allah. Ajaran Islam secara normatif mampu menjadi sumber motivasi yang kuat dalam mewujudkan etos kerja yang tinggi. ${ }^{34}$

Terdapat beberapa hasil penelitian yang menjadi acuan peneliti dalam melaksanakan penelitian ini. Pertama, Etos Kerja Wanita Dayak di Pedalaman Kalimantan Tengah yang dilakukan oleh Pusat Penelitian Wanita Universitas Palangkaraya. Simpulan penelitian menggambarkan bahwa peranan perempuan Suku Dayak sama kedudukannya dengan pria, baik dalam pola pekerjaan rumah tangga maupun dalam pola mencari nafkah, walaupun

Budaya Suku Bajo dalam Perlindungan dan Pemanfaatan Sumberdaya Laut di Sanana Utara Provinsi Maluku Utara", Jurnal Ilmiah Society, 1.17, 2015, h. 94-114. Hadi, Sumasno, "Studi Etika tentang Ajaranajaran Moral Masyarakat Banjar", Jurnal Tashwir, 3.6, 2015

33 Ahmad Janan Asifudin, Etos Kerja Islami (Telaah Psikologi), Disertasi Pasca Sarjana UIN Sunan Kalijaga, 2003, h. 19. Bandingkan dengan Saskara, Ida Ayu Nyoman, and Ghozali Maskie, "Tinjauan Perspektif Ekonomi dan Nonekonomi Perempuan Bali yang Bekerja di Sektor Publik: Studi Konflik Peran", Jurnal Aplikasi Manajemen, 10.3, 2012, h. 542-552

${ }^{34}$ Ahmad Janan Asifudin, Etos Kerja Islami (Telaah Psikologi)..., h. 39-44. Bandingkan dengan Pamuji, Imanuel Agung, "Pemberdayaan Perempuan Indonesia Maju Mandiri di Desa Rantau Layung Kecamatan Batu Sopang Kabupaten Paser", Jurnal Universitas Mulawarman, 1.1, 2017, h. 1-15. dengan beban curahan waktu yang berbeda. Perempuan sangat berperan dalam menunjang perekonomian rumah tangga, mereka bisa bekerja dalam berbagai bidang seperti berladang, mencari hasil hutan, menyadap karet, menangkap ikan dan sebagainya. ${ }^{35}$

Kedua, tentang "Etos Kerja Perempuan Dayak di Pinggiran Daerah Aliran Sungai (DAS) Kahayan Provinsi Kalimantan Tengah" yang dilakukan oleh Tim peneliti STAIN Palangka Raya. Temuan penelitian tersebut menegaskan bahwa etos kerja wanita Suku Dayak Kahayan pada empat kelurahan (Kelurahan Buntoi, Tumbang Nusa, Bukit Rawi dan Tangkahen) relatif tinggi, terutama dilihat dari jumlah jam kerja. Meskipun demikian, etos kerja mereka yang tinggi tidak ditunjang dengan kerjasama yang baik dengan teman sekerja dalam sebuah wadah seperti koperasi, sehingga hasil yang diperoleh tidak terlalu signifikan dalam upaya meningkatkan taraf hidup dan tingkat kesejahteraan mereka. ${ }^{36}$ Mencermati hasil penelitian yang telah dilakukan oleh para peneliti di atas, maka penelitian ini menelaah sisi lain yang belum tersentuh oleh para peneliti sebelumnya. Penelitian ini mengungkapkan bagaimana pandangan wanita pekerja rotan terhadap kerja, Siapa yang bertanggungjawab terhadap pemenuhaan kebutuhan pokok. Berdasarkan

${ }^{35}$ Ratnasari dkk, Etos Kerja Wanita Dayak di Pedalaman Kalimantan Tengah (Bandung: Unpar Press, 2005), h. 116. Bandingkan dengan Pollachom, Taweeluck, "Comparing Pathways and Outcome for Patani Muslim Women of Different Education Systems Since 1959", Islam Realitas: Journal of Islamic \& Social Studies, 1.2, 2015, h. 129-144.

${ }^{36}$ Tim Peneliti, Etos Kerja Perempuan Suku Dayak di Pinggiran Daerah Aliran Sungai (DAS) Kahayan Provinsi Kalimantan Tengah (Palangka Raya: Pusat Study Gender, 2005), h. 106. Prasojo, Zaenuddin Hudi, "Social Change and the Contributions of the Tionghoa, Dayak and Melayu (Tidayu) in West Kalimantan", Borneo Studies in History, Society and Culture. Springer, Singapore, 2017, h. 427-442. Kleden-Probonegoro, Ninuk, "Teater Mamanda dan Pendefinisian Kembali Identitas Banjar", Antropologi Indonesia, 21.1, 2014, h.21. 
pandangan mereka tersebut, maka muncul bagaimana sesungguhnya etos kerja wanita pekerja rotan di Desa Baru.

\section{Monograsi Desa Baru Sebagai Lokasi Penelitian}

Desa Baru merupakan salah satu dari 27 buah desa yang terdapat dalam wilayah Kecamatan Dusun Selatan Kabupaten Barito Selatan Provinsi Kalimantan Tengah. Desa ini memiliki 4 RW dan 12 RT. Luas wilayahnya 10.500 hektar. Jumlah penduduk 4.548 jiwa atau $1.303 \mathrm{KK} .{ }^{37}$ Desa ini terletak di pinggiran Sungai Barito.

Berdasarkan wawancara tim peneliti dengan kepala desa setempat, jumlah kebun rotan masyarakat sekitar 2.530 hektar sedangkan luas areal untuk berladang sekitar 33 hektar. Selain itu, tanah kosong atau lahan tidur yang masih belum tergarap cukup banyak dan beraneka tumbuh-tumbuhan terdapat di dalamnya. ${ }^{38}$

Penduduk Desa Baru mayoritas Suku Bakumpai, suku tersebut bagian dari Suku Dayak Ngaju. Ketika mereka masih berada di lebu (kampung) Bakumpai (Marabahan sekarang ini) dan sekitarnya, setelah memeluk agama Islam, maka mereka dinamai Suku Dayak Bakumpai atau ulub Bakumpai. ${ }^{39}$ Suku ini memiliki bahasa tersendiri, yakni Bahasa "Bakumpai".

\section{Etos-Etos Kerja Wanita Pekerja Rotan}

Berdasarkan data yang diperoleh tim peneliti di lapangan terhadap beberapa wanita pekerja rotan di Desa Baru yang dijadikan subjek dalam penelitian ini, dapat disarikan

\footnotetext{
${ }^{37}$ Monografi Desa Baru, 2014, h. 4.

${ }^{38}$ Bapak Suriadi, Kepala Desa Baru, Wawancara Pribadi, tanggal 27 - 28 Agustus 2016.

39 Alfani Daud, Islam dan Masyarakat Banjar, Disertasi (Pasca Sarjana IAIN Syarif Hidayatullah, 1990, h. 6-7, 43. Hidayah, M. Shohibul, "Konflik Komunal dan Resolusi Damai: Studi Kasus di Kalimantan Tengah", Psikologika: Jurnal Pemikiran dan Penelitian Psikologi, 7.13, 2002, h. 14-31.
}

pada tema-tema yang dikelompokkan pada etos kerja tinggi (uluh ji karetap bagawi, istilah setempat), dan rendah (ulub jijida hawas cangkal bagawi, istilah setempat) sebagaimana dalam pembahasan berikut ini.

\section{Bawi Ji Karetap Bagawi (Wanita yang Gigih Bekerja)}

Dalam diri wanita pekerja rotan ji karetap bagawi melekat kualitas "tahan banting". Rintangan-rintangan alam, seperti: kepanasan, di siang hari, banyaknya nyamuk, tempat bekerja yang harus menyeberangi sungai Barito dengan jukung halus (perahu kecil), terkadang anak yang masih kecil harus dibawa ke tempat kerja dan membuat tuyang (ayunan) untuk menidurkan anak, ditambah dengan kondisi harga terkadang berfluktuasi dan berdampak pada kuantitas rotan yang ada, acap kali tidak dihiraukan, dikalahkan oleh kemauan kerjanya yang memang tinggi atau gigih (karetap = bahasa setempat).

Wanita pekerja rotan yang tinggi etos kerjanya di Desa Baru disebut uluh ji karetap bagawi. 'orang yang gigih dan ulet dalam bekerja. Orang yang demikian hampir tidak ada waktu, ia selalu mengisi waktu dengan aktivitas kerja, yakni membersihkan rotan dari kulit-kulitnya.

Sebutan "ulub jikaretap bagawi" (orang yang gigih dan ulet/dalam bekerja, hampir tidak ada waktu istirahat) itu sesungguhnya lebih merupakan simbolik yang ditujukan kepada pekerja keras yang selalu tekun menggosok atau membersihkan rotan sehingga hasil yang diperoleh dalam sehari bisa mencapai 2 (dua) sampai 3 (tiga) kwintal

Salah satu ilustrasi dan repsentasinya tergambar pada wanita pekerja rotan bernama Santi. Menurut pengakuan subjek, ia sudah lebih dari puluhan tahun menekuni pekerjaan sebagai petani rotan. ${ }^{40}$

${ }^{40} \mathrm{Ibu}$ Santi, Wawancara Pribadi, tanggal 20 Maret 2017 
Dalam menjalankan pekerjaannya sebagai pekerja rotan, Ibu Santi harus berangkat pagi sebagaimana penjelasannya berikut.

Yakunah jam uju jadi tulak kan wadah bagawi, sabindai yaku tulak te yaku barapi manjubu belu, malibi akan anakkuluban dan akan bahata bagawi yakunab kuman sikanih, jida buli kan huma, mamalareh, amun buli pere bindai waktu takanan, buli bagawi sanja, tukep jam leme. Pakulib ije andau duwe sampai telu, huang ije minggu paling isut leme andau bagawi, tau kiya epat andau, amun ueweiyeb lepab. ${ }^{41}$

(Saya mulai bekerja sekitar pukul 07.00, sebelum berangkat ketempat kerja terlebih dahulu menyiapkan makanan untuk anakanak dan bapaknya serta untuk makan siang ditempat kerja, kalau siang pulang kerumah untuk memasak berapa waktu terbuang, pulang kerja sekitar pukul 17.00 dan apabila rotan banyak saya bekerja bisa sampai 5 hari dalam seminggu bisa juga empat hari karena bahan/ rotannya habi).

Pernyataan subjek di atas setidaknya ada tiga hal yang perlu digaris bawahi, pertama mengenai jam kerjanya, kedua mengenai jumlah hari bekerja dalam seminggu dan ketiga adalah penghargaannya terhadap waktu.

Bekerja dimulai pukul 0.7.00 sampai dengan pukul 17.00 WIB berarti Ibu Santi bekerja dalam sehari kurang lebih 10 (sepuluh) jam. Kemudian ia istirahat untuk makan siang ssekitar 60 menit atau 1 (satu) jam, maka masih tersisa sekitar 9 (sembilan) jam waktu untuk bekerja. Jumlah jam kerja yang demikian, apabila dikalikan dengan jumlah hari kerjanya selama 5 hari dalam 1 (satu) minggu, maka berarti subjek bekerja sebanyak 45 jam dalam seminggu. Jumlah jam kerja yang demikian mengindikasikan semangat kerja yang tinggi.

Dumairy menjelaskan dalam bukunya, seseorang dikatakan bekerja penuh (tinggi),

41 Ibu Santi, Wawancara Pribadi, tanggal 21 Maret 2017. apabila jam kerjanya telah mencapai mencapai setidak-tidaknya 35 jam kerja dalam seminggu. Di daerah pedesaan jumlah jam kerja yang paling banyak dijalani adalah antara 35 hingga 44 jam dalam seminggu. ${ }^{42}$

Selain jumlah jam kerjanya yang tinggi, subjek juga, sangat menghargai waktu sebagaimana penjelasan subjek di atas. Waktu adalah amanah yang harus dipertanggug jawabkan. Betapapun, penghargaan dan pemanfaatan waktu merupakan salah satu yang harus menjadi perhatian seseorang termasuk para pekerja. Manajemen dan disiplin waktu menjadi sangat penting jika seorang ingin mencapai kesuksesan dalam bekerja.

Sebaik pembanding, waktu bagi seorang Muslim adalah rahmat yang tiada terhitung nilainya. Baginya pengertian terhadap makna waktu merupakan rasa tanggung jawab yang sangat besar. Sehingga sebagai konsekuensi logisnya dia menjadikan waktu sebagai wadah produktivitas. Ada semacam bisikan dalam jiwanya jangan lewatkan barang sedikit pun kehidupan ini tanpa memberi arti. ${ }^{43}$

Selain memberi penghargaan terhadap waktu, ibu Santi juga sangat memperhatikan akan hasil (output) kerjanya. Sebagaimana penjelasan subjek di bawah ini.

"Hasil pekerjaan saya harus bersih, saya tidak mau bekerja sembarangan, pemiliknya bisa tidak percaya lagi dan mata saya juga tidak enak melihat hasilnya."

Pernyataan di atas jelas sekali, bahwa ibu Santi selalu mengutamakan output pekerjaan yang berkualitas, ia tidak mau hasil pekerjaannya berkualitas rendah sehingga pemberi kerja atau majikan tidak percaya lagi padanya.

42 Dumairy, Perekonomian Indonesia, Cet. II (Jakarta: PT Gelora Aksara Pratama, 1997), h. 83-84.

43 Toto Tasmara, Etos Kerja Pribadi Muslim (Yogyakarta: PT Dana Bhakti Wakaf, 1995), h. 31-32. 
Islam tidak semata-mata memerintahkan bekerja, tetapi bekerja dengan baik. Hendaknya seorang Muslim ibsan dalam bekerja dan dilaksanakan dengan penuh ketekunan dan kesungguhan. Bahkan tegasnya al-Quran tidak cukup menyuruh manusia untuk beramal yang baik saja, tetapi menyuruh amal/pekerjaan yang terbaik. ${ }^{44}$

Selain itu, Ibu Santi juga tampaknya memiliki pandangan yang positif terhadap kehidupan keluarganya pada masa yang akan datang, ia menginginkan agar kehidupan keluarganya bisa lebih baik, oleh karena itu bekerja dengan sungguh-sungguh pada saat masih muda sangat diperlukan, sebagaimana pernyataannya saat diwawancara:

... yaku umba bagawi mamparasib uwey bikaunah mangat kawa manabung, umba arisan, jibikaunah akan itah bakas kareh, yakunah bacita-cita amun arep bakas kareh tamangat kiya pambelum, anakuluban te ile jikakilau pambelum arep tuh. ${ }^{45}$ (Saya bekerja membersih rotan agar bisa ikut arisan ibu-ibu untuk tabungan untuk masa tua, saya ingin kehidupan selanjutnya lebih baik dan anak-anak tidak lagi mengalami kehidupan seperti saya).

Komitmen kerja keras dengan harapan memperoleh kelebihan rezeki dari kebutuhan dasar sehingga dapat digunakan untuk ikut arisan dan menabung untuk persiapan masa tua merupakan cita-cita yang mulia dan baik. Masa depan memang perlu dipersipkan dari sekarang agar tidak timbul penyesalan di kemudian hari ${ }^{46}$.

${ }^{44}$ Yusuf al-Qardhawi, Peran Nilai dan Moral dalam Perekonomian Islam, terj. Didin Hafidhuddin (Jakarta: Rabbani Press, 1997), h. 160-161.

${ }^{45}$ Ibu Santi, W awancara Pribadi, tanggal 20 Maret 2017.

46 Jonathan, Lca Robin, "Efektifitas Kebijaksanaan Pemerintah, Sumber Daya dan Budaya Ekonomi Terhadap Peningkatan Pemberdayaan Ekonomi Masyarakat di Provinsi Kalimantan Timur", Dedikasi, 35.2, 2016, h. 1-12.
Memulai bekerja dari pukul 07.00 pagi dan pulang sekitar pukul 15.00 disertai dengan 5 hari kerja dalam seminggu apabila rotan memang banyak juga dilakoni oleh ibu Ranah. Frekwensi jam kerja subjek dalam sehari sekitar 8 sampai 9 jam dapat disimak dari penuturannya di bawah ini.

... bekerja dimulai pukul 07.00 , pagi menyiapkan makanan setelah semua sudah diselesaikan di rumah seperti makanan untuk anak-anak, baru berangkat ketempat kerja, saya membawa makanan untuk makan siang ditempat kerja, sore baru pulang sekitar pukul 15.00 , supaya hemat waktu. ${ }^{47}$

Penjelasan di atas mendeskripsikan jumlah jam kerja yang tinggi dan sekaligus kemampuannya mengatur waktu sehingga ia bekerja tidak mengganggu tugasnya sebagai ibu rumah tangga.

Selain keuletannya dalam bekerja dan kemampuannya mengatur waktu disisi lain, subjek juga merupaya bisa mengatur keuangan rumah tangga dengan baik. Hal ini dapat disimak dari penjelasan ibu Ranah ketika dilakukan wawancara oleh tim peneliti sebagai berikut: "Apabila ada kelebihan dari hasil bekerja, hendaklah dibelanjakan dengan baik, artinya jangan boros, membeli hal-hal yang tidak prioritas, namun jangan pula kikir, subjek mempraktikkannya dengan menggemgam tangannya sambil berucap jida mahantis danum silenge (tidak menetes air ditangan, ini ada simbolik terhadap orang yang sangat kikir). Belanjakan sesuai dengan keperluan dan kalau ada sisanya agar disimpan untuk masa tua".

Sikap hemat, dan pandai menghitung antara pendapatan dengan pengeluaran memang harus dimiliki oleh seorang ibu rumah tangga yang juga merangkap sebagai pekerja yang ingin meraih kesuksesan di masa depan. Berhemat bukanlah dikarenakan ingin

${ }^{47}$ Ibu Ratnah, Wawancara Pribadi, tanggal 20 Maret 2016 
menumpuk harta kekayaan sehingga melahirkan sifat kikir, melainkan ada satu pandangan bahwa tidak selamanya waktu itu berjalan secara lurus, ada naik ada turun, sehingga berhemat berarti bisa menghitung apa yang akan terjadi di masa datang.

Lawan dari berhemat adalah berlebihlebihan atau boros. Perilaku boros merupakan sifat yang tidak terpuji dan tidak boleh melekat pada pribadi Muslim, termasuk wanita pekerja rotan di Desa Baru yang ingin berhasil.

Jika ditinjau dari segi agama, Islam mengajarkan sikap pertengahan (equilibrium) dalam segala urusan. Begitu pula dalam mengeluarkan atau membelanjakan harta, tidak berlebih-lebihan atau boros dan tidak pula kikir.(QS al- Furqān [25]: 67).

Etos kerja seseorang bisa ditegorikan tinggi, bukan hanya diliht dari jumlah jam kerjanya dalam seminggu, namun juga bisa dilihat dari kemampunnya dalam mengatur penggunaan waktu dan bagaimana pandangannya terhadap masa yang akan datang, apakah ia ingin lebih baik atau sebaliknya.

Djamaluddin Ancok menyebutkan, orang yang etos kerjanya baik atau tinggi, memiliki ciri-ciri sebagai berikut : 1) Selalu ingin bekerja keras untuk mencapai kualitas kerja yang sebaik-baiknya; 2) Selalu ingin meningkatkan prestasi kerjanya dari hari ke hari. Mereka tergolong orang yang menerapkan prinsip hidup bahwa apa yang diperbuat hari ini harus lebih baik dari apa yang telah diperbuat kemaren; 3) Selalu merasa tidak puas dengan hasil pekerjaan yang asal jadi. Mereka akan puas dengan pekerjaan yang bermutu tinggi. ${ }^{48}$

Subjek lainnya yang memiliki jam kerja yang tinggi dalam bekerja, dilakoni pula oleh

48 Djamaluddin Ancok, Nuansa Psikologi Pembangunan (Yogyakarta: Pustaka Pelajar,1995), hlm. 165.
Ibu Ilus. Ibu ini sudah lama menjalani sebagai petani rotan, malah menurut pengakuannya sebelum ia berkeluarga. Pekerjaan ini ia warisi dari ibunya. Dalam masalah berapa jam dan berapa hari bekerja dapat disimak dari penuturan subjek di bawah ini.

Yaku tulak bagawi nah jam uju, hayakjewn barapi manjubu belu, malibi akan anakkuluban, akan apaeh dan akan bahata kuman bentuk andau kareh, yaku jida buli kan buma, mamalareh, amun buli pere bindai waktu takanan, buli bagawi sanja, tukep jam leme. Pakulib ije andau dune sampai telu pikul, buang ije minggu paling isut leme andau bagawi, tau kiya epat andau, amun neweiyeh lepah. ${ }^{49}$

(Saya berangkat bekerja sekitar pukul 07.00, paginya terlebih dahulu menyiapkan makanan untuk anak-anak dan bapaknya serta untuk makan siang di tempat kerja, kalau siang pulang kerumah untuk memasak berapa waktu terbuang, pulang kerja sekitar pukul 17.00 dan apabila rotan banyak saya bekerja bisa sampai 5 hari dalam seminggu apabila rotan sedikit bisa 4 hari saja).

Beranjak dari penuturan Ibu Ilus di atas mengenai jumlah jam kerja dalam sehari tampak ia memiliki semangat kerja yang tinggi, di mana dalam seminggu ia bekerja tidak kurang dari 40 jam.

Para kaum ibu yang bekerja selain untuk membantu suami mencukupi kebutuhan pokok keluarga, juga sebahagian hasil kerjanya bisa disisihkan untuk membiayai sekolah anakanaknya. Subjek dikarunia 3 (tiga) orang anak, dan semuanya laki-laki. Anak yang pertama sudah lulus SMA dan sudah bekerja di pabrik karet di Baru. Anak yang nomor 2 (dua) sedang kuliah di IAIN Palangka Raya mengambil Prodi Biologi dan yang terakhir baru kelas 1 SMPN Dusun Selatan.

2017.

\footnotetext{
${ }^{49}$ Ibu Ilus, Wawancara Pribadi, tanggal 20 Maret
} 
Meskipun pendidikan subjek para kaum ibu tidak terlalu tinggi (hanya tamatan SDN) saja, namun tampaknya pendidikan anak-anak menjadi perhatian serius ibu beranak 3 ini sebagaimana tercermin dari pernyataannya di bawah ini.

... ikey nah belum susah, belum jida tapi baduit dan jida bailmu, yaku jida bakun hindai anakuluban belummeh kakilau ikey tub, yaku dan banangkub nab babarap samandeyah anakkuluban te kawa sakulah satinggi-tinggi eh, amun iye bailmu, iye tau manjalani pambelum dengan baik, ela sampai anakuluban kakilau ikey ji bakastuh.

(...kami orang yang miskin, tidak punya uang miskin ilmu pengetahuan, saya tidak mau anak anak saya seperti kami. Saya dan suami sepakat agar semua anak-anak kami bisa menjalani pendidikan setinggi-tingginya, dengan berilmu ia bisa menjalani kehidupan ini dengan baik, tidak lagi seperti orang tuanya).

Subjek tidak ingin anak-anaknya mewarisi kemiskinan dan kebodohan seperti yang terjadi pada diri mereka. Oleh karena itu Ibu Ilus berupaya bekerja sekuat tenaga membantu suaminya menambah pendapatan sehingga anak-anaknya bisa sekolah.

Apa yang dicita-citakan dan dilakukan subjek sejalan dengan anjuran agama. Allah swt menegaskan dalam $\mathrm{Al}$ Quran surat An Nisa ayat 9 .

Berinvestasi di bidang pendidikan dan membekali anak-anak dengan ilmu pengetahuan sangat baik dan dianjurkan agama. Meminjam pendapat Jansen Sinamo, jika ingin melahirkan orang beretos kerja yang baik, harus diimbangi dengan pengetahuan yang memadai. ${ }^{51}$ Senada dengan Sinamo, Muhammad Thalhah Hasan menegaskan,

${ }^{50} \mathrm{Ibu}$ Ilus, Wawancara Pribadi, tanggal 21 Maret

51 Jansen Sinamo, 8 Etos Kerja Profesional, Cet. Kesepuluh (Jakarta: Institut Darma Mahardika, 2011), h. 338. pendidikan pada dasarnya merupakan usaha pengembangan sumber daya manusia (SDM). ${ }^{52}$

Membekali anak dengan pendidikan agar kehidupan anak-anak jadi lebih baik, meskipun orang tua bekerja membanting tulang, diamini oleh ibu Ismayanti. Subjek yang satu itu sempat mengenyam pendidikan sampai lulusan SMPN di Buntok.

Dilihat dari jumlah hari kerjanya memang ia hanya diberi jatah 4 hari saja untuk bekerja sebagai pekerja rotan oleh suaminya, namun di rumah pada saat ia tidak bekerja sebagai pekerja rotania bekerja membuat kue dan kerupuk. Hasilnya juga cukup lumayan sehingga hasil pekerjaan subjek bisa mengikuti arisan ibu-ibu di kampungnya. Arisan tersebut dipandangnya sebagai tabungan untuk persiapan anak-anaknya sekolah nanti sebagaimana petikan wawancara berikut ini.

Saya baru dikarunia satu orang anak dan sedang duduk di kelas dua SDN. Saya bekerja sebagai pekerja rotanhasilnya bisa membantu perekonomian keluarga. Selain bekerja sebagai pekerja rotan saya juga membikin kerupuk untuk dijual. Dikampung banyak ubi kayu yang bisa dibuat menjadi kerupuk. Alhamdulillah sebahagian hasil dari membuat kerupuk bisa ditabung. Dalam hal bekerja yang penting halal saya tidak mau yang pilihpilih... ${ }^{53}$

Apa yang dilakukan subjek seperti penjelasan di atas menggambarkan ketulusan, kecerdasan dan kecermatan dalam melihat peluang usaha, dan hal itu tidak disiasiakannya. Gambaran sifat di atas merupakan salah satu indikasi orang yang memiliki etos kerja yang baik.

Gunnar Myrdal dalam Ahmad Janan Asifuddin menjelaskan bahwa indikasi orang

${ }^{52}$ Muhammad Thalhah Hasan, Islam dan Masalab Sumber Daya Manusia (Jakarta: Lantabora Press, 2003), h. 131.

${ }^{53} \mathrm{Ibu}$ Lismayanti, Wawancara Pribadi, tanggal 12 Maret 2017. 
ber-etos kerja tinggi di antaranya, rasional dalam mengambil keputusan dan gesit dalam memanfaatkan kesempatan. ${ }^{54}$

Kerajinan bekerja yang tertanam dalam diri Ibu Lismayanti, kejelian melihat peluang usaha membikin kerupuk yang bahan mentahnya banyak terdapat di kampung, yang mungkin tidak semua orang bisa melihat peluang seperti itu dan berbuah keuntungan yang bisa tabung sebagai persiapan masa depan.

Subjek mengakui bahwa hasil dari membuat kerupuk tidak besar untungnya, namun katanya hal itu perlu disyukuri. Karena tidak sedikit ibu rumah tangga yang tidak memiliki penghasilan. Sedikit demi sedikit akhirnya menjadi banyak, tambahnya.

Syukur versi subjek adalah jangan menggerutu, apapun hasil yang didapatkan setelah bekerja, sebagaimana penjelasannya berikut.

... saya pernah dinasehati oleh kakek, ketika beliau masih hidup, katanya, kalian jangan menyalahkan si pemberi rezeki (Tuhan), meskipun rasa ketidak puasan itu hanya tersirat dalam hati, terima dengan hati yang lapang apa yang diberi-Nya. Tuhan mengetahui keperluan hamba-Nya, yang penting harus bekerja. Nasehat tersebut saya pegang sampai sekarang.

Penerapan syukur oleh subjek, terlihat dalam aktivitas menghadapi pekerjaan sebagai petani rotan, penjual kerupuk di rumah dan keliling kampung. Subjek selalu tenang, ceria dalam menjalani pekerjaannya, meskipun cuaca terkadang hujan, sehingga tidak bisa bekerja.

54 Ahmad Janan Asifuddin, Etos Kerja Islami (Surakarta: Muhammadiyah University Press, 2004), h. 35. Lihat pula M. Quraish Sihab, Berbisnis dengan Allah (Tangerang: Lentera Hati, 2008), h. 25.

${ }^{55}$ M. Quraish Sihab, Berbisnis dengan Allah......, h.
Ikhtiar mencari karunia Allah (rezeki) dengan cara bekerja memang menjadi kewajiban setiap manusia, namun bagaimana hasilnya itu sudah hak prerogatif Yang Maha Kuasa dan hasil yang didapat wajib disyukuri. Jadi apa yang dilakukan oleh subjek dengan selalu bersyukur atas hasil kerjanya sudah sejalan dengan ajaran Islam.

Subjek lainnya yang juga digolongkan memiliki jam kerja sekitar 40 jam dalam semingga adalah ibu Wahidah. Sebagaimana petikan wawancana tim dengan ibu berana tiga ini sebagai berikut.

... yaku bagawinah sakitar jam uju, buli eh jam leme sanja. Huang ije minggu tau karen leme andau yaku bagawi, amun uwey te kosong, yaku nah mawi wadai akan jual. Manjualleh yaku kiya mananjung mangakiking kampung, lepah beh dan tahan beh basilleh. Tau kiya belahbeh inabung, karen akan aanukuluban sakulah kareh, yakunah jida mangat asaiyeh amun jida bagawi. ${ }^{56}$ (Saya mulai mulai bekerja sekitar pukul 07.00 dan pulang sore hari sekitar pukul 17.00 WIB. Dalam seminggu saya bekerja sebagai petani rotan 5 hari. Apabila rotan kosong, maka saya bekerja membuat kue dan saya jual sendiri, keliling kampung, hasilnya luyaman saja, sebahagian bisa ditabung untuk anak-anak sekolah, kalau menganggur saya kurang enak).

Petikan wawancara di atas di samping menggambarkan frekwensi jam kerja subjek, juga menggambarkan kerajinannya dalam bekerja dan menciptakan peluang kerja. Misalnya apabila rotan yang akan dibersihkan kosong, maka ia bekerja lain yang bisa mendatangkan hasil seperti membuat kue untuk dijual. Selain itu Ibu Wahidah ini tidak suka kalau ia menganggur alias tidak bekerja dan yang menariknya lagi hasil kerjanya

${ }^{56} \mathrm{Ibu}$ Wahidah, Wawancara Pribadi, tanggal 19 Maret 2017. 
sebahagian bisa ditabung untuk biaya anakanaknya sekolah.

Subjek tampaknya tidak ingin mewariskan kepada anak-anaknya pendidikan yang rendah apalagi sampai putus sekolah lantaran ketiadaan biaya seperti yang ia alami. Hal ini dapat dipahami dari penjelasannya berikut ini.

Tidak mengapa bekerja siang malam istilahnya asal anak-anak saya bisa terus sekolah, saya berharap dengan sekolah anak-anak hidupnya akan lebih baik, jangan lagi mereka seperti kami orang tuanya ini. ${ }^{57}$

Harapan agar kehidupan anak-anak menjadi lebih baik menjadi dambaan setiap orang tua termasuk subjek. Dan harapan tersebut dibuktikannya dengan bekerja apa saja yang penting halal, baik sebagai pekerja rotan atau membuat kue dan sebahagian hasilnya ia tabung untuk kepentingan anak-anaknya sekolah.

\section{Bawi Jijida Hawas Cangkal Bagawi (Wanita yang Kurang Giat Bekerja)}

Aktivitas keseharian bawi jijida hawas cangkal bagawi kurang tergerak untuk mengoptimalkan tenaga dan jam kerja dalam seminggu dan mencari pekerjaan lain selain menjadi pekerja rotan apabila rotan kebetulan kosong $^{58}$.

Wanita petani yang jida hawas cangkal bagawi, dapat digolongkan sebagai wanita pekerja rotan yang rendah semangat kerjanya. Salah satu ilustrasi dan representasinya tergambar pada seorang Ibu Norhidayah. Bekerja sebagai pekerja rotan cukup lama dijalaninya, yakni lebih dari puluhan tahun.

Maret 2017.

${ }^{57}$ Ibu Wahidah, Wawancara Pribadi, tanggal 19

58 Pamuji, Imanuel Agung, "Pemberdayaan Perempuan Indonesia Maju Mandiri di Desa Rantau Layung Kecamatan Batu Sopang Kabupaten Paser", Jurnal Universitas Mulawarman, 1.1, 2017, h. 1-15.
Berapa jam dan berapa hari ia bekerja dalam seminggu dapat disimak dari penuturannya berikut ini.

...yaku mulai bagawinah sekitar jam uju, kareh bentok anadau istirahat buli kan buma, kuman bentuk andau. Kareb tulak bindai sekitar jam duwe, jam epat te buli, jewn mubun hindai. Huang ije minggu te tau empat andau, tau kiya telu andau beh ji bagawi eh. Yaku nah jida kakilau kakawalan ji babimat bagawi, sasadang beh. ${ }^{59}$ (Saya mulai bekerja pukul 07.00, nanti sekitar pukul 12.00 istirahat pulang ke rumah untuk makan siang. Kemudian pukul 14.00 berangkat lagi dan pukul 16.00 pulang kerja, besok begitu lagi. Dalam satu minggu bisa empat hari, bisa juga tiga hari bekerja. Saya bekerja tidak seperti teman-teman yang bekerja keras, saya sedang-sedang saja).

Memperhatikan penuturan subjek di atas, maka dapat dikalkulasikan bahwa jumlah jam kerjanya dalam sehari berkisar antara 6 sampai 7 jam. Kemudian sekiranya ia bekerja selama 4 hari, maka jumlah jam kerjanya berkisar 24 sampai dengan 28 jam dalam seminggu dan jika ia hanya bekerja 3 hari dalam seminggu maka jumlah jam kerja sekitar 18 sampai dengan 21 jam dalam seminggu. Jumlah jam kerja yang demikian memang mengindikasikan semangat kerja yang rendah.

Selanjutnya dari penuturan subjek di atas juga tersirat bagaimana pengakuannya bahwa ia tidak seperti wanita lain yang giat bekerja, ia tampaknya semacam membatasi kesibukannya dalam bekerja dan tidak mau berikhtiar menambah pekerjaan lain selain membersihkan rotan.

Tampaknya subjek kurang tertarik untuk mencari pekerjaan lain selain sebagai pekerja rotan untuk menambah jumlah pemasukan sehingga tingkat ekonomi keluarga bisa lebih

${ }^{59} \mathrm{Ibu}$ Norhidayah, Wawancara Pribadi, tanggal 20 Maret 2017. 
baik. Tampaknya ia lebih tertarik untuk istirahat dan bekerja seadanya saja.

Bawi jida hawas cangkal bagawi (wanita yang rendah semangat kerjanya) juga terdapat pada wanita pekerja rotan lainnya yang bernama Ibu Ratnah. Subjek yang berusia sekitar 41 dan lahir di Desa Baru Kabupaten Barito Selatan.

Di Desa Baru dan sekitarnya mayoritas yang bekerja sebagai pembersih rotan dari kulitnya adalah kaum ibu. Hal ini dapat dipahami bahwa para ibu dalam mengerjakan sesuatu termasuk dalam hal kebersihan selalu teliti. Juragan rotan pernah diwawancara tim, ia sampai saat ini lebih mempercayakan pekerjaan membersihkan rotan itu kepada ibuibu dibandingkan bapak-bapak.

Ibu Ratnah menuturkan kepada tim peneliti ia sejak duduk di bangku SD sudah sering diajak orang tuanya bekerja sebagai petani rotan. Lama-kelamaan setelah melihat dan mengamati apa yang dilakukan orang tuanya, akhirnya ia pun bisa dan pandai bekerja menggosok rotan, sebagaimana penjelasannya berikut ini.

Ketika masih anak-anak saya sering dibawa ibu bekerja membersibkan rotan, saya ingat sekali semenjak saya duduk di bangku SD. Karena keseringan dibawa dan melibat orang bekerja, akbirmya saya itu bisa... ${ }^{60}$

Rotan yang sudah dibersihkan oleh pekerja wanita, lalu diangkut atau diambil oleh pekerja laki-laki dan dijemur, atau dikeringkan sampai kadar kandungan airnya kira-kira 5-10 $\%$. Setelah kering, maka rotan tersebut diikat (inggalung = bahasa setempat) satu ikatan beratnya bisa mencapat 40-60 kg.

Selanjutnya subjek menuturkan bahwa dalam seminggu ia bekerja paling banyak 4 hari sebagaimana penuturannya berikut ini.
Huang ije minggu, yakunah epat andau beh bagawi, tulak kan wadah bagawi tukep jam hanya, bentuk andau buli kuman, kareh jam duwe tulak bindai sekitar jam epat sanja buli ai, jewu bindau amun ada uwey yeh. ${ }^{61}$ (Dalam satu minggu saya bekerja hanya empat hari, berangkat pukul hampir pukul 08.00, tengah hari pulang istirahat makan siang, jam dua berangkat lagi dan sekitar pukul empat sore pulang ke rumah, besok lagi bekerja bila rotannya masih ada, kalau tidak ada ya istirahat, dalam sehari hasil yang dperoleh sekitar 25 ribu).

Memperhatikan penjelasan subjek di atas, jumlah jam kerja Ibu Ratnah dalam sehari berkisar 6 jam saja. Apabila ia bekerja selama 4 hari dalam seminggu, maka jumlah jam kerjanya dalam seminggu hanya sekitar 24 jam saja.

Keterampilan lain seperti membuat kerupuk, membikin kue, bikin anyaman dari rotan, tidak dimiliki oleh Ibu Ratnah. Jadi bekerja sebagai pekerja rotan saja yang bisa dilakukannya. Oleh karenanya apabila rotan selaku bahan mentahnya kosong, ibu ini istirahat bekerja, ia bekerja kembali apabila rotan ada lagi.

Tidak tergerak untuk melakukan pekerjaan lain seperti membuat kue, kerupuk dan lainnya, bisa juga karena ketidakbisaan, atau keterampilan untuk itu tidak ada, bila pula karena bosan lantaran sudah terlalu lama mengerjakan pekerjaan itu saja dan hasil yang signifan belum diperoleh, selain itu mungkin juga disebabkan oleh faktor pendidikan.

Kondisi semangat kerja yang kurang dan jam kerja rendah juga tergambar pada subjek yang bernama Ibu Tiah. Hal ini dapat dipahami dari petikan wawancara tim dengan subjek sebagai berikut.
${ }^{60} \mathrm{Ibu}$ Ratnah, Wawancara Pribadi, tanggal 19 Maret 2017.
${ }^{61}$ Ibu Ratnah, Wawancara Pribadi, tanggal 19 Maret 2017 
Saya bekerja dalam seminggu bisa empat hari, bisa juga hanya tiga hari. Saya kan sebagai ibu rumah tangga, jadi bekerjanya tidak seperti kaum pria. Saya mulai bekerja sekitar pukul 07.00, pukul 12.00 pulang ke rumah untuk makan siang dan sekitar pukul 14.00 berangkat kerja lagi, kurang lebih pukul 16.00 pulang. ${ }^{62}$

Penjelasan subjek di atas jelas sekali bahwa frekwensi jam kerjanya dalam seminggu berkisar 24 sampai dengan 28 jam saja. Gambaran jam kerja yang demikian mengindikasikan semangat kerja yang rendah.

Selain jumlah jam kerja subjek yang rendah, ia juga tidak memiliki keterampilan kerja lainnya seperti yang dimiliki oleh sebagian ibu-ibu pekerja rotan yang bisa bikin kerupuk singkong, kue untuk dijual, dengan menggunakan tanaman singkong dan pisang di samping atau di belakang rumah sebagaimana penuturan subjek berikut ini.

Amun pas uwey te lepabi, yaku parai bagawi,

kareh menunggu dumah uweyyeh beh. Maawi

karen karupuk jawau, pisang goreng akan jual

jida piji manggawi eh, karena pisang, jawau

bikaunah jida maimbulleh kiya, padahal ada beb isut petak silikur buma bikaunab. ${ }^{63}$

Penjelasan subjek di atas semakin memperjelas, bahwa sebagai petani rotanlah satu-satunya pekerjaan yang bisa ia lakukan selama ini. Membuat kue dan kerupuk singkong untuk dijual ia tidak pernah melakukannya, padahal menurut pengakuannya dibelakang rumahnya masih ada tanah yang kosong dan bisa untuk bertanam, namun tidak dilakukannya.

Tampaknya subjek kurang tertarik untuk mencari pekerjaan lain selain sebagai pekerja rotan untuk menambah jumlah pemasukan sehingga tingkat ekonomi keluarga bisa lebih Maret 2017

${ }^{62} \mathrm{Ibu}$ Tiah, Wawancara Pribadi, tanggal 21 Maret 2017 baik. Tampaknya ia lebih tertarik untuk istirahat dan bekerja seadanya saja.

Krisis semangat kerja bisa membuat orang malas melakukan perubahan, tidak mau berpikir ke depannya bagaimana. Hasil yang ada sudah dianggap cukup, sehingga membuat rendahnya semangat untuk berprestasi lebih baik dan membuat orang menjadi statis.

Memperhatikan paparan etos kerja wanita pekerja rotan di Desa Baru di atas, maka keenam subjek (Ibu Santi, Ibu Ranah, Ibu Wahidah, Ibu Ismayanti, dan Ibu Ilus) termasuk bawi ji karetap bagawi (wanita yang rajin bekerja) dengan indikasi jumlah jam kerja yang tinggi, jumlah jam kerja kelima subjek berkisar antara 38 sampai dengan 45 jam dalam satu minggu, berorientasi pada kualitas kerja, memiliki prinsip bahwa hari ini harus lebih baik dari kemaren dan besok harus lebih baik dari sekarang, pandai menghargai waktu, mampu melihat dan memanfaatkan peluang yang ada, dan hemat.

Semangat kerja tinggi dan perilaku positif keenam subjek di atas tampaknya juga pengaruhi oleh pandangan bahwa bekerja bukan hanya sebatas pemenuhan kebutuhan fisiologis, tetapi kerja juga dipahami sebagai sarana untuk membiayai keberlangsungan pendidikan anak dan juga sebagai sarana untuk menabung untuk persiapan di masa tua ${ }^{64}$.

Sikap pandai menghargai waktu, rajin dalam bekerja, pendidikan sangat penting sebagai bekal hidup anak-anak menjalani kehidupan di masa yang akan datang, hemat yakni sebahagian pendapat ditabung untuk persiapan masa tua, sejalan dengan ajaran Islam. Dengan demikian sikap positif di atas, bisa saja dipengaruhi ajaran agama yang mereka yakini dan pahami.

64 Datta, Sanghita, "Bangladeshi Muslim Construction Workers in Singapore: a Study in the Process of Migration and Employment", Islam Realitas: Journal of Islamic \& Social Studies, 1.2, 2015, h. 117-127. 
Pemahaman seseorang terhadap agama yang dianutnya tidaklah sama, ia memiliki tahap-tahap perkembangan, jika tahap perkembangan keagamaan seseorang, berada pada tahap keyakinan, yang meyakini agama sebagai kebenaran tanpa syarat, maka akan berbeda dengan etos kerja seorang yang beragama pada tahap pemikiran, yang mencari landasan rasional atas kebenaran suatu agama, dan tentunya juga akan berbeda dengan etos kerja seorang beragama pada tahapan penemuan, yang memantapkan kebenaran aktifitas keagamaan pada kedalaman hati nuraninya sendiri. Pada tahap yang ketiga ini, kedalaman agama menjadi sesuatu yang bersifat internal, bukan sesuatu yang eksternal. 65

Dengan demikian, etos kerja mereka selain kemungkinannya dipengaruhi oleh ajaran agama, atau pengaruh dari dalam (intern), juga dipengaruhi oleh lingkungan sosial atau pengaruh dari luar (ekstern) ${ }^{66}$. Dalam penelitian ini, membangun etos kerja yang tinggi, tampaknya dipengaruhi oleh sikap mental yang tertanam dalam diri mereka, atau dipengaruhi unsur dari dalam (intern) dan dipengaruhi oleh faktor luar (ekstern). Dalam praktiknya sebagian besar subjek memadukan paham mentalisme yang dimunculkan oleh Max Weber dan sekaligus paham strukturalisme.

Paham mentalisme secara garis besar menganggap bahwa struktur alam atas atau alam pemikiran manusia, merupakan bagian dari kesadaran manusia di dalam upaya untuk dapat mengubah atau menentukan sejarah dalam memaknai dunia. Struktur alam pemikiran manusia menjadi alat yang sangat penting dalam upaya menafsirkan lebih lanjut

${ }^{65}$ Musa Asy'arie, Islam Etos ..., h. 35-36.

66 Sofiani, Triana, "Manifestasi Perlindungan Hukum Berkeadilan Gender Berbasis Pemahaman Hak dan Kewajiban Hukum dalam Hubungan Kerja", Jurnal Penelitian, 5.1, 2013, h. 32. terhadap dunia yang akan punya pengaruh terhadap sikap dan tingkah laku seseorang dalam gerak hidup di dunia ini. ${ }^{67}$ Sedangkan paham strukturalisme mengatakan bahwa bukan kesadaran yang menentukan keadaan dan waktu, melainkan kondisilah yang menentukan kesadaran. ${ }^{68}$

Jika berbicara masalah etos kerja memang tidak bisa dilepaskan dari asumsi dasar bahwa peran manusia sebagai pelaku dari kerja itu sendiri sangatlah penting. Manusia sebagai pelaku utama punya peran penting yang sangat menentukan. Artinya, kesadaran manusia atau nilai-nilai yang berada dalam diri manusia menjadi faktor yang sangat menentukan sikap manusia dalam memaknai dunia ini. Namun faktor lingkungan atau pengaruh dari luarpun tidak bisa diabaikan. Kedua paham tersebut, yakni paham mentalisme dan strukturalisme oleh keenam subjek dalam riset ini dipraktikkan secara terpadu? ${ }^{69}$.

Kedua teori yang dikemukakan para ahli sebagaimana disebutkan di atas (teori mentalisme dan strukturalisme) oleh keenam subjek (uluh bagi ji karetap bagawi) di Desa Baru dipandang sebagai sebagai sesuatu yang saling mendukung, saling bekerjasama. Keduanya tidak saling bertentangan, tetapi saling melengkapi untuk membangun semangat kerja yang tinggi.

Selanjutnya ketiga subjek (Ibu Norhidayah, Ibu Ratnah dan Ibu Tiah) yang memiliki semangat kerja rendah, bekerja apa

${ }^{67}$ Uswatun Hasanah, Etos Kerja Sarana Menuju Puncak Prestasi (Yogyakarta: Harapan Utama, 2004), h. 11. Mirhan, A. M., "Agama dan Politik di Kalimantan Selatan", Jurnal Ilmiah Ilmu Ushuluddin, 15.2, 2017, h. 111-121.

${ }^{68}$ M. Dawam Rahardjo, Islam dan Transformasi Sosial-Ekonomi (Jakarta: LSAF, 1999), h. 248 Lihat pula Uswatun Hasanah, Etos Kerja ..., h. 15.

${ }^{69}$ Asyari, Asyari. "Model Strategi Bertahan Hidup Rumah Tangga Miskin (Sebuah Literature Review) ", Islam Realitas: Journal of Islamic \& Social Studies, 2.2 2016, h. 153-164. 
adanya saja, tidak mampu memanfaatkan waktu, tidak berupaya mencari kerja sampingan apabila rotan kosong, tidak punya visi ke depan, kemungkinana ada kaitannya dengan tingkat pendidikan mereka dan bisa jadi dipengaruhi oleh lingkungan.

Dalam bekerja apa saja, termasuk sebagai pekerja rotan memang diperlukan keuletan, dan kesabaran. Sabar bukan berarti pasrah menerima keadaan tanpa ikhtiar. Sabar menghadapi pekerjaan walaupun terasa berat dan membosankan. Semakin banyak seseorang bekerja, semakin banyak hasil yang didapatkannya, sebaliknya semakin sedikit orang melakukan aktivitas kerja semakin kecil pula pendapatan yang diperolehnya.

\section{Kesimpulan}

Terdapat 2 (dua) varian etos kerja wanita pekerja rotan di Desa Baru. Pertama, etos kerja uluh bawi ji karetap bagawi. Bagi wanita yang memiliki semangat kerja yang baik atau tinggi (karetap bagaml) dengan ciri-ciri sebagai berikut: Memiliki jam kerja yang tinggi, mereka bekerja berkisar antara 38 sampai 45 jam dalam seminggu. Pandai menghargai waktu, bila ada waktu kosong diupayakan untuk mengisinya dengan bekerja yang menghasilkan uang. Kualitas kerja atau mengutamakan output pekerjaan yang lebih baik. Mampu melihat peluang dan sekaligus mengeksekusi peluang tersebut untuk menambah penghasilan. Memiliki pandangan bahwa hari ini harus lebih baik dari kemaren dan besok harus lebih baik dari hari ini. Berpandangan bahwa pendidikan bagi anak sangat penting dan lebih diutamakan serta hemat dalam membelanjakan pendapatan, yakni tidak boros. Mereka yang tergolong bawi ji kabariat bagawi (etos kerja tinggi) sebanyak 5 orang, yakni Ibu Santi, Ibu Ratnah, Ibu Ilus, Ibu Lismayanti dan Ibu Wahidah. Kedua, etos kerja Bawi jigida hawas cangkal bagawi. Bagi wanita pekerja rotan yang memiliki semangat kerja rendah dengan ciriciri memiliki jumlah jam kerja rendah, yakni mereka bekerja berkisar antara 18 sampai dengan 28 jam dalam seminggu. Mereka tidak mampu memanfaatkan waktu. Kurang kreatif dalam menciptakan pekerjaan lainnya yang bisa menambah penghasilan dan mereka tidak memiliki pandangan kedepan yang lebih baik atau positif. Subjek yang tergolong memiliki semangat kerja yang rendah adalah Ibu Norhidayah, Ibu Ratnah dan Ibu Tiah.

\section{Daftar Pustaka}

\section{Buku Teks}

Abdullah, Amin, Studi Agama: Normativitas dan Historisitas (Yogyakarta: Pustaka Pelajar, 1999).

--------, Islam dan Keseimbangan Rasionalitas, Moralitas dan Spiritualitas (Yogyakarta: LESFI, 2005).

Abdullah, Taufik. (ed.), Agama, Etos Kerja dan Perkembangan Ekonomi, cet. ke-2, Jakarta: LP3S, 1982).

Agus, Bustanuddin, Agama Dalam Kehidupan Manusia Pengantar Antropologi Agama (Jakarta: Raja Grafindo Persada, 2006).

Alatas, Mitos Pribumi Malas, Citra orang Jawa, Melayu dan Filipina dalam Kapitalisme Kolonial, terj. Ahmad Rofi'i, Jakarta: LP3ES, 1988).

Ancok, Djamaluddin, Psikologi Terapan Mengupas Dinamika Kehidupan Manusia (Yogyakarta: Darussalam, 2004).

dan Suroso Fuat Nashori, Psikologi Islam Sulusi Islam atas Problem-Problem Psikologi, cet. ke-8, (Yogyakarya, Pustaka Pelajar, 2011)

Asifudin, Ahmad Janan, Etos Kerja Islami (Surakarta: Muhammadiyah University Press, 2004).

Asy'ari, Musa, Islam Etos Kerja dan Pemberdayaan Ekonomi Umat (Yogyakarta: LESFI, 1997. 
Budiman, Arief, Teori Pembangunan Dunia Ketiga (Jakarta: PT Gramedia Pustaka Utama, 1996).

Bukhārī al-Imām Abū 'Abd Allah Muḥammad Ibn Ismā'ūl, Șaḥị̣ Bukhārū, Jilid III, Juz VIII, Kitab ad-Da'wât, Bab alTa'awwudz min al-Ma'tsam wa alMagram, (Jakarta: Maktabah Asy-Syurūq al-Dauliyah al-Qāhirah, t.th).

Bungin, Burhan, Penelitian Kualitatif, cet. ke-4 (Jakarta: Kencana Prenada Media Group, 2010).

Daryono, Etos Dagang Orang Jawa Pengalaman Raja Mangkunegara IV (Yogyakarta: Pustaka Pelajar, 2007).

Hasanah, Uswatun, Etos Kerja Sarana Menuju Puncak Prestasi (Yogyakarta: Harapan Utama, 2004).

Miles, Matthew. B., Huberman, Michael.A, Analisa Data Kualitatif, terj. Tjetjep Rohandi Rohidi, Jakarta: UI-Press, 2009).

Mubyarto. Dkk., Etos Kerja dan Kohesi Sosial (Yogyakarta: Aditya Media, 1991).

Muhadjir, Noeng, Metodologi Penelitian Kualitatif, Edisi IV, (Yogyakarta: Rake Sarasin, 2000).

Qodir, Zuly, Agama dan Etos Dagang, (Surakarta: Pondok Edukasi, 2002).

Sastrahidayat, Ika Rochdjatun, Membangun Etos Kerja dan Logika Berpikir Islami (Malang: UIN Malang Press, 2009).

Shihab, M. Quraish, Berbisnis dengan Allah (Tangerang: Lentera Hati, 2008).

-------, Membumikan Al-Qur'an Jilid 2, (Tangerang: Lentera Hati, 2011).

Sinamo, Jansen, 8 Etos Kerja Profesional, cet. ke10, (Jakarta: Institut Darma Mahardika, 2011).

Tasmara, Membudayakan Etos Kerja Islami (Jakarta: Gema Insani Press, 2002).
Usman, Sunyoto, Pembangunan dan Pemberdayaan Masyarakat (Yogyakarta: Pustaka Pelajar, 1998).

Weber, Max, The Protestant Ethic and The Spirit of Capitalism, trans. Talcott Parsons (London and New York: Routledge, 1930).

Ya'qub, Hamzah, Etos Kerja Islami, Jakarta: CV Pedoman Ilmu Jaya, 2001.

\section{Jurnal}

Alfisyah, Alfisyah, "Dinamika Ekonomi dan Perkembang Perdagangan Urang Banjar", Jurnal Kebudayaan Kandil-Melintas Tradisi, 6.16, 2008.

-, "Etika Dagang "Urang Banjar”", Jurnal Kebudayaan Kandil-Melintas Tradisi, 16, 2012.

Asyari, Asyari. "Model Strategi Bertahan Hidup Rumah Tangga Miskin (Sebuah Literature Review) ", Islam Realitas: Journal of Islamic \& Social Studies, 2.2 2016.

Datta, Sanghita, "Bangladeshi Muslim Construction Workers In Singapore: a Study in the Process of Migration and Employment", Islam Realitas: Journal of Islamic \& Social Studies, 1.2, 2015.

Desky, Harjoni, "Pengaruh Etos Kerja Islami dan Gaya Kepemimpinan terhadap Kinerja Karyawan Rumah Makan Ayam Lepaas Lhokseumawe", Inferensi Jurnal Penelitian Sosial Keagamaan, 8.2, 2014.

Gorontalo, Rifani, "Modernisasi dan Perubahan Sosial Budaya Suku Bajo dalam Perlindungan dan Pemanfaatan Sumberdaya Laut di Sanana Utara Provinsi Maluku Utara", Jurnal Ilmiah Society, 1.17, 2015.

Hadi, Sumasno, "Studi Etika Tentang Ajaranajaran Moral Masyarakat Banjar", Jurnal Tashwir, 3.6, 2015.

Herwanti, Hj Titiek, "Pengaruh Pendapatan, Lama Kerja dan Status Famili Terhadap Remitan Tenaga Kerja Wanita Propinsi 
Nusa Tenggara Barat", Ekuitas Jurnal Ekonomi dan Keuangan, 15.1, 2017.

Hidayah, M. Shohibul, "Konflik Komunal dan Resolusi Damai: Studi Kasus di Kalimantan Tengah", Psikologika: Jurnal Pemikiran dan Penelitian Psikologi, 7.13, 2002.

Jonathan, Lca Robin, "Efektifitas Kebijaksanaan Pemerintah, Sumber Daya dan Budaya Ekonomi Terhadap Peningkatan Pemberdayaan Ekonomi Masyarakat di Provinsi Kalimantan Timur", Dedikasi, 35.2, 2016.

Kleden-Probonegoro, Ninuk, "Teater Mamanda dan Pendefinisian Kembali Identitas Banjar", Antropologi Indonesia, 21.1, 2014.

Mirhan, A. M., "Agama dan Politik di Kalimantan Selatan", Jurnal Ilmiah Ilmu Ushuluddin, 15.1, 2017.

Pamuji, Imanuel Agung, "Pemberdayaan Perempuan Indonesia Maju Mandiri di Desa Rantau Layung Kecamatan Batu Sopang Kabupaten Paser", Jurnal Universitas Mulawarman, 1.1, 2017.

Pollachom, Taweeluck, "Comparing Pathways and Outcome for Patani Muslim Women of Different Education Systems Since 1959", Islam Realitas: Journal of Islamic \& Social Studies, 1.2, 2015.

Prasetyo, P. E., "Etos Kerja Wanita dalam Meningkatkan Kesejahteraan Keluarga", Jurnal Forum Ilmu Sosial, Vol. 32, 2005.

Prasojo, Zaenuddin Hudi, "Social Change and the Contributions of the Tionghoa, Dayak and Melayu (Tidayu) in West Kalimantan", Borneo Studies in History, Society and Culture. Springer, Singapore, 2017.

Salaa, Jeiske, "Peran Ganda Ibu Rumah Tangga dalam Meningkatkan Ekonomi Keluarga di Desa Tarohan Kecamatan Beo Kabupaten Kepulauan Talaud", Jurnal Holistik, 3.2, 2015.
Saskara, Ida Ayu Nyoman, and Ghozali Maskie, "Tinjauan Perspektif Ekonomi dan Non-Ekonomi Perempuan Bali yang Bekerja di Sektor Publik: Studi Konflik Peran", Jurnal Aplikasi Manajemen, 10.3, 2012.

Sofiani, Triana, "Manifestasi Perlindungan Hukum Berkeadilan Gender Berbasis Pemahaman Hak dan Kewajiban Hukum dalam Hubungan Kerja", Jurnal Penelitian, 5.1, 2013.

Sugiyanto, Roso, and Tatik Upami, "Makna Budaya Lokal dalam Usaha Peningkatan Pendapatan Keluarga Sejahtera (UPPKS)(Studi Kasus Kelompok UPPKS di Kalimantan Tengah)", JIPSINDO, 2.2, 2013.

Sulaksono, Dwi Putra, "Masyarakat Desa dan Proses Sosial Menuju Perubahan Kebudayaan", Dinamika Kearifan Lokal Masyarakat Kalimantan, 21.2, 2005.

Wahyuni, Devi, "Kebijakan Kepemimpinan Perempuan dalam Pendidikan Islam: Refleksi Atas Kepemimpinan Rky Rahmah El Yunisiyah", Islam Realitas: Journal of Islamic \& Social Studies, 3.1, 2017.

Yulianti, Rahmani Timorita, Mega Octaviani, "Pengaruh Agama dan Budaya terhadap Etos Kerja Pebisnis Muslim Suku Bugis di Kabupaten Nunukan Kalimantan Utara", Millah: Jumal Studi Agama, 14.1, 2014. 